\title{
KUALITAS FISIK DAGING DADA DAN PAHA BROILER YANG DIRENDAM DALAM LARUTAN DAUN SALAM (Syzygium polyanthum)
}

\author{
Physical Quality of Breast and Thight of Meat Broiler that Immersed \\ in Bay Leaf (Syzygium Polyanthum) Liquid
}

\author{
Dian Septinova, Madi Hartono, Purnama Edy Santosa, Siti Hartika Sari \\ Department of Animal Husbandry, Faculty of Agriculture, Lampung University \\ Soemantri Brojonegoro No. 1, Gedong Meneng, Rajabasa, Bandar Lampung 35145 \\ E-mail: dian.septinova@yahoo.com
}

\begin{abstract}
The objectives of the study were (1) to know there was or no interaction between soaking time in bay leaf and type of carcass to the physical quality of broiler meat; (2) To know the duration of optimum immersion for the physical quality of the muscles of the breast and thighs. This research was arranged using Completely Randomized Design (RAL) with factorial pattern. The first factor is the length of meat immersion in bay leaf solution, namely: P0: control; P1 (20 minutes); P2 (40 minutes); P3 (60 minutes). While the second factor is a piece of carcass, namely: K1 (thigh) and K2 (chest). Each treatment was repeated 3 times. The research variables were pH of meat, WHC, and cooking loss. The data obtained were proceed to variance analyze and further tested by BNT Test for length of immersion and Tukey test for carcass type at $5 \%$ level of significant. The results showed that there was no interaction $(P>0,05)$ between soaking time and carcass cut. The duration of immersion had no significant $(P>0,05)$ effect on $p H, W H C$, and cooking loss. Carcasses cut of thight and breast have a significant effect $(P<0,05)$ on $\mathrm{pH}$ and cooking loss, but are not significant $(P>0,05)$ for WHC. The $p H$ value of the thigh meat is significantly $(P<0,5)$ higher than the breast, but the cooking loss is lower.
\end{abstract}

Keywords : Bay Leaf, Breast, Thight, Broiler, Physical Quality

\section{PENDAHULUAN}

Daging broiler merupakan bahan pangan asal ternak yang kaya akan nutrisi dan relatif banyak dikonsumsi oleh masyarakat Indonesia. Namun, daging broiler mudah mengalami kerusakan (perishable food) sebagai akibat adanya reaksi kimia, enzimatik, dan aktivitas mikroba terurama bakteri yang berlangsung secara bersamaan. Umumnya, bakteri pembusuk merupakan penyebab utama kerusakan pada daging. Bakteri pembusuk yang terdapat pada daging adalah Pseudomonas, Acinetobacter, Lactobacillus, dan Brochothrix thermosphacta (Kotula dan Kotula, 2000).

Upaya pengawetan perla dilakukan untuk mempertahankan kualitas dan memperpanjang masa simpan daging agar tetap aman untuk dikonsumsi. Teknik pengawetan daging dapat dilakukan secara fisik seperti penyimpanan pada suhu rendah, pembekuan, radiasi, dan pengemasan modified atmophere dan secara kimia seperti penggunaan alkohol, penol, dan nitrat serta nitrit. Namun demikian, pengawetan dengan menggunakan bahan alami yang mudah diperoleh dan tidak mengganggu kesehatan sebagai pengawet lebih dianjurkan. Bahan alami yang mempunyai potensi untuk dijadikan sebagai pengawet daging broiler salah satunya adalah daun salam.

Daun salam mengandung flavonoid, tannin, minyak atsiri, triterpenoid, alkaloid, dan steroid. Flavonoid, tannin, minyak atsiri, dan alkaloid memiliki efek antibakteri sedangkan steroid triterpenoid dan steroid memiliki efek analgesik (Kusuma et al., 2011). Flavonoid adalah golongan terbesar dari senyawa fenol. Senyawa fenol memiliki kemampuan antibakteri dengan cara mendenaturasi protein yang menyebabkan terjadinya kerusakan permeabilitas dinding sel bakteri (Cushnie dan Lamb, 2011). Tannin bersifat sebagai antibakteri karena tannin dapat mengganggu permeabilitas membran sel bakteri dan memiliki kemampuan mencegah koagulasi plasma pada Staphylococcus aureus (Akiyama et al., 2001). Minyak atsiri berperan sebagai antibakteri dengan cara mengganggu enzim yang membantu pembentukan energi sehingga memperlambat pertumbuhan sel. Minyak atsiri dalam jumlah banyak dapat juga mendenaturasi protein (Nazzaro et al., 2013). Mekanisme alkaloid 
sebagai antibakteri adalah dengan cara mengganggu komponen penyusun peptidoglikan pada sel bakteri, sehingga lapisan dinding sel tidak terbentuk secara utuh dan menyebabkan kematian sel tersebut (Kurniawan \& Aryana, 2015).

Aplikasi lama perendaman dengan pengawet alami dapat mempengaruhi efektifitas penghambatan terhadap bakteri selama penyimpanan (Sudarmawan, 2010; Saraswati 2015). Lamanya waktu perendaman dengan menggunakan bahan pengawet dapat berpengaruh terhadap kualitas daging (Agustina et al., 2012 dan Rohman et al., 2015). Hal tersebut disebabkan daging memiliki cukup waktu untuk menyerap kandungan yang terdapat pada bahan pengawet sehingga zat aktif dalam bahan dapat bekerja secara efektif. Selain lama perendaman, jenis potongan karkas juga merupakan salah satu faktor yang dapat mempengaruhi kualitas daging (Soeparno, 2005). Daging paha dan dada adalah bagian potongan karkas yang paling banyak disukai dan dikonsumsi oleh masyarakat. Daging paha dan dada broiler mempunyai karakteristik fisikokimia yang berbeda.

Berdasarkan uraian di atas, maka perlu dilakukan penelitian untuk mengetahui pengaruh lama perendaman dengan menggunakan larutan daun salam terhadap kualitas fisik daging paha dan dada broiler yang meliputi $\mathrm{pH}$, daya ikat air, dan susut masak. Tujuan penelitian ini adalah: (1) untuk mengetahui ada tidak interaksi antara lama perendaman dalam daun salam dan macam potongan karkas terhadap kualitas fisik daging broiler; (2) untuk mengetahui lama perendaman optimum untuk kualitas fisik daging paha dan dada.

\section{MATERI DAN METODE}

\section{Materi}

Materi yang digunakan pada penelitian ini yaitu daging yang diberi perlakuan larutan daun salam dari hasil perebusan daun salam segar, aquades, dan daging broiler bagian paha dan dada. Broiler yang digunakan yaitu broiler jantan berumur 1 bulan dan memiliki bobot $1 \mathrm{~kg}$.

\section{Metode}

Metode penelitian yang digunakan adalah percobaan menggunakan Rancangan Acak Lengkap (RAL) dengan pola faktorial. Faktor pertama adalah lama perendaman daging dalam larutan daun salam, yaitu kontrol (P0), 20 menit (P1), 40 menit (P2), dan 60 menit (P3). Faktor kedua adalah jenis potongan karkas, yaitu : paha (K1) dan dada (K2). Masing-masing perlakuan diulang sebanyak 3 kali. Data yang diperoleh dianalisis ragam dan diuji lanjut dengan Uji BNT untuk lama perendaman dan Uji Turkey untuk macam potongan karkas. Pengujian dilakukan pada taraf nyata $5 \%$.

\section{Tahapan Pelaksanaan}

\section{Pembuatan larutan daun salam}

Tahapan yang dilakukan dalam pembuatan larutan daun salam mengikuti Pura (2015) yaitu memblender daun tua dengan sedikit air dan menambahkan air pada hasil blender tersebut. Perbandingan antara air dengan daun salam yaitu 1:2 (b/v). Larutan daun salam dimasak hingga mendidih selama 15 menit. Selanjutnya melakukan penyaringan dan mencampur larutan daun salam dengan aquadest dengan perbandingan (1:4).

\section{Persiapan perlakuan daging broiler}

Daging broiler bagian dada dan paha (masing-masing sebanyak 12 potong) direndam pada larutan daun salam sesuai dengan lamanya waktu perendaman yang digunakan $(0,20,40$, dan 60 menit). Selanjutnya meniriskan daging broiler, menyimpannya selama 8 jam (setelah pemotongan) pada suhu ruang, dan melakukan pengamatan pada daging.

\section{Peubah}

Peubah yang diamati adalah nilai $\mathrm{pH}$ (Mach et al., 2008), Daya Ikat Air (Kisseh et al., 2009), dan susut masak (Kaoba, 2003).

\section{HASIL DAN PEMBAHASAN}

\section{Pengaruh Perlakuan terhadap Nilai pH}

Nilai $\mathrm{pH}$ daging akan turun saat postmortem. Penurunan nilai $\mathrm{pH}$ tersebut terjadi karena proses glikolisis anaerob yang merubah glikogen menjadi asam laktat. Nilai $\mathrm{pH}$ daging paha dan dada broiler yang direndam dalam larutan daun salam dengan lama perendaman yang berbeda dapat dilihat pada Tabel 1 .

Tabel 1. Nilai pH, DIA, dan susut masak daging paha dan dada pada lama perendaman yang berbeda

\begin{tabular}{lcccccc}
\hline \multirow{2}{*}{ Peubah } & \multirow{2}{*}{$\begin{array}{c}\text { Jenis } \\
\text { Otot }\end{array}$} & \multicolumn{4}{c}{ Lama Perendaman (menit) } & \multirow{2}{*}{ Rataan } \\
\cline { 3 - 6 } & & $\mathbf{0}$ & $\mathbf{2 0}$ & $\mathbf{4 0}$ & $\mathbf{6 0}$ & \\
\hline pH & Paha & 6,52 & 6,65 & 6,66 & 6,65 & $6,62^{\mathrm{a}}$ \\
& Dada & 6,13 & 6,07 & 6,27 & 6,18 & $6,16^{\mathrm{b}}$ \\
\hline $\begin{array}{l}\text { DIA } \\
(\%)\end{array}$ & Paha & 51,81 & 50,17 & 44,47 & 50,62 & 50,48 \\
& Dada & 50,00 & 47,21 & 46,59 & 53,57 & 49,34 \\
\hline $\begin{array}{l}\text { Susut } \\
\text { Masak } \\
(\%)\end{array}$ & Paha & 18,82 & 19,23 & 19,88 & 19,21 & $19,29^{\mathrm{a}}$ \\
\hline
\end{tabular}


Nilai pH daging berkisar antara 6,346,94 pada daging paha dan $6,00-6,33$ pada daging dada. Hasil analisis ragam menunjukkan bahwa tidak ada interaksi antara lama perendaman dan jenis otot $(\mathrm{P}>0.05)$. Lama perendaman daging broiler dalam larutan daun salam berpengaruh tidak nyata $(\mathrm{P}>0,05)$ terhadap nilai $\mathrm{pH}$ daging, namun jenis potongan daging berpengaruh nyata $(\mathrm{P}<0,05)$. Nilai $\mathrm{pH}$ otot paha nyata $(\mathrm{P}<0,05)$ lebih tinggi dibanding otot dada.

Lama perendaman berpengaruh tidak nyata terhadap nilai $\mathrm{pH}$ daging. Hasil penelitian ini berbeda dengan hasil penelitian Sudarmawan (2010) dan Saraswati (2015). Perbedaan disebut disebabkan oleh perbedaan sifat bahan pengawet dan jenis daging yang digunakan. Menurut Sudarmawan (2010), aplikasi lama perendaman biopreservatif berbasis bawang putih mempengaruhi efektifitas penghambatan terhadap bakteri L. monocytogenes selama penyimpanan. Lama perendaman selama 10 menit efektif menghambat pertumbuhan $L$. monocytogenes selama penyimpanan 24 jam pada suhu ruang, sedangkan lama perendaman 20 menit, masih efektif menghambat pertumbuhan L. monocytogenes setelah penyimpanan 24 jam. Pengaruh lama perendaman terhadap efektifitas penghambatan pertumbuhan bakteri juga dinyatakan oleh Saraswati (2015), bahwa pada lama perendaman ikan tuna selama $0,10,20,30,40$, dan 50 menit dalam larutan daun sirih, lama perendaman 50 menit paling efektif untuk menghambat pertumbuhan bakteri.Nilai $\mathrm{pH}$ yang relatif sama pada lama perendaman yang berbeda disebabkan oleh konsentrasi larutan daun salam yang rendah. Daun salam mengandung flavonoid.

Konsentrasi larutan daun salam yang rendah menyebabkan kandungan zat flavonoid yang terdapat dalam larutan menjadi sedikit, begitu pula yang terserap masuk ke dalam daging. Jumlah flavonoid tersebut pada daging kontrol dan daging yang direndam dengan larutan daun salam selama 20, 40, dan 60 menit pun diduga relatif sama. Akibatnya aktifitas enzim ATP-ase pada daging semua perlakuan relatif sama. Menutut Taufiq et al. (2015), zat aktif flavonoid dapat menghambat aktifitas enzim ATP-ase. Enzim ATP-ase adalah enzim yang memecah glikogen menjadi asam laktat pada proses glikolisis anaerob. Jumlah asam laktat yang terbentuk akan menentukan nilai $\mathrm{pH}$ daging.

Nilai $\mathrm{pH}$ daging paha nyata $(\mathrm{P}<0,05)$ lebih tinggi dibanding daging dada setelah direndam dalam larutan daun salam dan disimpan 8 jam setelah pemotongan. Hasil ini sesuai dengan hasil penelitian Choe et al. (2010), chang dan Chou (2010); Yu et al. (2011), Mbaga et al. (2014), dan Promket et al. (2016) bahwa nilai $\mathrm{pH}$ daging dada lebih rendah dibanding bagian kaki atau paha.

Perbedaan $\mathrm{pH}$ daging paha dan dada tergantung pada proses glikolisis yang terjadi yang merupakan indikasi yang jelas dari status biokimia daging dan laju glikolisis intramuskular (Thielke et al., 2005). Penurunan nilai pH daging postmortem, secara normal berkaitan dengan akumulasi asam laktat pada otot selama glikolisis (Lawrie, 2003). Akumulasi asam laktat selama glikolisis postmortem ini dipengaruhi oleh jenis otot dan laju glikolisis. Menurut $\mathrm{Yu}$ et al. (2011), daging dada ayam mempunyai lebih banyak serabut putih dibanding daging kaki yang lebih banyak serabut merah. Menurut Berri et al. (2005), metabolime energi yang terjadi pada otot dada ayam adalah metabolisme anaerob, bahkan saat ternak tersebut masih hidup. Artinya jumlah glikogen pada otot bagian dada lebih banyak. Hal tesebut didukung oleh hasil penelitian Yu et al. (2011), bahwa setelah lama simpan 6 jam jumlah glikogen daging dada $(1,01 \mathrm{mg} / \mathrm{g})$ nyata lebih tinggi dibanding daging paha $(0,81 \mathrm{mg} / \mathrm{g})$.

Hal lain yang menyebabkan nilai $\mathrm{pH}$ daging dada yang lebih rendah dari daging paha adalah laju glikolisis daging dada yang relatif lebih cepat sehingga asam laktat yang terbentuk lebih banyak dan $\mathrm{pH}$ daging dada menjadi lebih rendah. Menurut Berry et al. (2005), peningkatan proses glikolisis dapat terjadi jika hewan menggunakan otot tersebut untuk gerak yang lebih cepat. Otot dada memang bukan otot gerak, namun otot tersebut digunakan oleh ayam untuk menunjang kecepatan geraknya.

Perbedaan aktifitas antara otot bagian paha dan dada juga menyebabkan timbunan glikogen pada kedua otot menjadi berbeda. Otot paha lebih banyak bergerak sehingga jumlah timbunan glikogennya banyak yang digunakan sebagai energi untuk aktivitas gerak. Akibatnya jumlah glikogennya pun menjadi lebih sedikit, kemudian jumlah asam laktat yang terbentuk pada proses glikolisis anaerob menjadi sedikit pula, sehingga $\mathrm{pH}$ daging paha menjadi lebih tinggi dibanding otot dada.

Berdasarkan nilai $\mathrm{pH}$, maka daging paha $(6,62)$ termasuk dalam kategori daging Dark, Firm, Dry (DFD) dan daging dada $(6,16)$ masuk dalam kategosi daging normal. Menurut Husak et al. (2008), laju dan tingkat penurunaan nilai $\mathrm{pH}$ mempunyai pengaruh yang besar terhadap karakteristik kualitas daging. Menurut Ristic dan Klaus (2010), kualitas daging dapat ditentukan dari nilai $\mathrm{pH}$, yaitu $\leq 5,8$ (Pale, Soft, Exudate (PSE)), 5,9—6,2 (normal), dan $\geq 6,3$ (DFD). 


\section{Pengaruh Perlakuan terhadap Daya Ikat Air}

Daya Ikat Air (DIA) adalah kemampuan protein daging untuk mengikat air atau menahan air yang ditambahkan dari luar. DIA merupakan salah satu indikator penentuan kualitas daging. Nilai DIA daging pada penelitian ini berkisar antara 44,83-60,71\%.

Hasil analis ragam menunjukkan bahwa tidak ada interaksi $(\mathrm{P}>0,05)$ antara lama perendaman dan jenis potongan karkas terhadap DIA daging broiler. Lama perendaman dan jenis otot berpengaruh tidak nyata $(\mathrm{P}>0,05)$ terhadap DIA. Nilai DIA yang berbeda tidak nyata pada lama perendaman yang berbeda dalam larutan daun salam disebabkan oleh nilai $\mathrm{pH}$ yang juga tidak berbeda nyata. Hal ini sesuai dengan pendapat Soeparno (2005) bahwa terdapat pengaruh yang kuat antara nilai $\mathrm{pH}$ dengan DIA daging. Pada daging yang nilai $\mathrm{pHnya}$ di atas $\mathrm{pH}$ isolektrik daging $(5,0-5,1)$, semakin tinggi nilai $\mathrm{pH}$ maka DIA akan semakin tinggi.

Nilai DIA daging yang tidak berbeda nyata pada berbagai lama perendaman juga disebabkan oleh rendahnya kandungan fenol dari larutan daun salam. Senyawa fenol mampu mengikat gugus aldehid, keton, dan ester yang dapat memengaruhi kemampuan mengikat air pada daging.

Fenomena yang sama terjadi pada penelitian Yu et al. (2010). Hasil penelitian Yu et al. (2011) memperlihatkan bahwa nilai $\mathrm{pH}$ daging dada nyata $(\mathrm{P}<0,5)$ lebih rendah dari kaki setelah penyimpanan, namun drip lossnya tidak berbeda nyata $(\mathrm{P}>0,05)$. Hubungan antara DIA dan drip loss dijelaskan oleh Soeparno (2005) bahwa kemampuan daging untuk mengikat airnya dapat dilihat dari drip-nya.

\section{Pengaruh Perlakuan terhadap Susut Masak}

Nilai susut masak daging pada penelitian ini berkisar antara 15,82-35,56\%. Semakin kecil nilai susut masak secara nutrisi semakin baik karena semakin sedikit nutrien daging yang hilang. Nilai susut masak yang lebih kecil pun lebih menguntungkan secara ekonomi.

Hasil analisis ragam menunjukkan bahwa tidak terdapat interaksi $(\mathrm{P}>0,05)$ antara lama perendaman daging broiler dalam daun salam dan jenis otot terhadap susut masak. Lama perendaman berpengaruh tidak nyata $(\mathrm{P}>0,05)$ terhadap susut masak daging, namun jenis potongan karkas berpengaruh nyata $(\mathrm{P}<0,05)$. Susut masak pada potongaan paha nyata lebih rendah $(\mathrm{P}<0,05)$ dibanding otot dada.

Pada perlakuan lama perendaman daging dalam larutan daun salam, susut masak tidak berbeda nyata $(\mathrm{P}<0,05)$ karena nilai $\mathrm{pH}$ dan DIA daging juga tidak berbeda. Yanti et al., (2008) menyatakan bahwa susut masak daging dipengaruhi oleh DIA. Semakin tinggi DIA semakin tinggi susut masak daging. Menurut Suradi (2006), susut masak juga dipengaruhi oleh nilai $\mathrm{pH}$ yang dikuti oleh kemampuan daging dalam mengikat air. Susut masak daging paha nyata lebih rendah dari daging paha. Hal ini disebabkan oleh $\mathrm{pH}$ dan DIA daging paha yang lebih tinggi. DIA daging mengalami perubahan oleh perlakuan pemanasan.

Hasil penelitian ini berbeda dengan hasil penelitian Promket et al. (2016) bahwa susut masak daging paha yang dimasak dengan cara perebusan lebih tinggi dibanding daging dada. Perbedaan tersebut dapat disebabkan oleh banyak faktor. Menurut Soeparno (2005), susut masak dipengaruhi oleh lama pemanasan, suhu pemanasan, umur ternak, bangsa, berat ternak, jumlah lemak, dan konsumsi ransum.

\section{SIMPULAN}

Tidak ada interaksi antara lama perendaman dan jenis otot terhadap $\mathrm{pH}$, DIA, dan susut masak daging paha dan dada. Lama perendaman berpengaruh tidak nyata terhadap $\mathrm{pH}$, DIA, dan susut masak. Perendaman selama 0 - 60 menit masih dapat mempertahankan kualitas daging paha dan dada ditinjau dari $\mathrm{pH}$, DIA, dan susut masak. pH daging dada lebih tinggi disbanding daging dada tetapi susut masak lebih rendah.

\section{DAFTAR PUSTAKA}

Agustina, F.D., Widyaningrum, P., Yuniastuti, A. 2012. Efek perendaman infusa daun salam (Syzygium Polyanthum) terhadap kualitas daging ayam postmortem. Jurnal Biosaintifika 4 (2): $78-82$

Akiyama, H. Fuji, K., Yamasaki, O., Oono, T., Iwatsuki, K. 2001. Antibacterial action of several tannins against Staphylococcus aureus. The Journal ofAntimicrobial Chemotherapy 48(4): 487—491

Berri, C.I., Debut, M., Santé-Lhoutellier V., Arnould. C., Boutten, B., Sellier, N., Baéza, E., Jehl, N., Jégo, Y., Duclos, M.J., and Le Bihan-Duval, E. 2005. Variations in chicken breast meat quality: implications of struggle and muscle glycogen content at death. British Poultry Science 46 (5): 572-579

Chang, Y.S. and Chou, R.G. 2010. Postmortem degradation of desmin and calpain in breast and leg and thigh muscles from 
Taiwan black-feathered country chickens. J. Sci. Food Agric 90: 2664-2668

Choe, J. H., Nam, K. C., Jung, S. M., Kim, B. N., Yun, H. J., and Jo, C. R. 2010. Differences in the quality characteristics between commercial Korean native chickens and broilers. Korean J. Food Sci. 30: $13-19$

Cushnie, T.P.T., and Lamb, A.J. 2011. Recent advances in understanding the antibacterial properties of flavonoids. International Journal of Antimicrobial Agents 38 (2): 99-107

Husak, R.L., Sebranek, J.G., and Bregendahl, K. 2008. A survey of commercially available broilers marketed as organic, free-range, and conventional broilers for cooked meat yields, meat composition, and relative value. Journal Poultry Science 87: 23672376meat composition, and relative value. Journal Poultry Science 87: 23672376

Nazzaro, F., Fratianni, F., De Martino, L., Coppola, R., De Feo, V. 2013. Effect of essential oils on pathogenic bacteria. Pharmaceuticals 6 (12): 1451- 1474

Kaoba, M. 2003. Quality of Organic Animal Products. Lives Production Science. Dallas.

Kissel, C., Adriana L.S., Alessandro, R., and Masssami, S. 2009. Functional properties of PSE (Pase, Soft, Exudative) broiler meat in the production of Mortadella. Brazilian Archives of Biology and Technology an International Journal $52: 35-43$

Kotula, K.L. and Kotula, A.W. 2000. Microbial ecology of different types of food fresh red meats. In: The Microbiological Safety and Quality of Food. Lund, B.M., Parker, T.C.B., and Gould, G.W (Eds). Aspen Publishers Inc. Gathersburg.

Kurniawan, B., and Aryana, W.F. 2015. Binahong (Cassia alata $\mathrm{L}$ ) as inhibitor of Escherichia coli growth. Majority Journal 4 (4): 100-104

Kusuma, I.W., Kuspradini, H., Arung, E.T., Aryani, F., Min, Y.H., Kim, J.S., and Kim, Y.U. 2011. Biological activity and phytochemical analysis of three Indonesian medicinal plants, Murraya koenigii, Syzygium polyanthum and Zingiber purpurea. Journal of Acupuncture and Meridian Studies 4 (1): 75-79

Mach, N., Bach, A., Velarge, A., and Devant, M. 2008. Association between animal, transportation, slaughterhouse and meat
pH in beef. J. Meat Science 78 (4): 232 238

Mbaga, S.H., Sanka, Y.D., Katule, A.M., and Mushi, D. 2014. Effects of storage time on the quality of local chicken meat. Tanzania Journal of Agricultural Sciences 13 (1): 48-54

Pura, E. A., Suradi, K., Suryaningsih, L. 2015. Pengaruh berbagai konsentrasi daun salam (Syzygium polyanthum) terhadap daya awet dan akseptabilitas pada karkas ayam broiler. Jurnal Ilmu Ternak 15 (2): $33-38$

Promket, D., Ruangwittayanusorn, K., and Somchan, T. 2016. The study of carcass yield and meat quality in crossbreed native chicken (chee). Agriculture and Agricultural Science Procedia 11: $84-$ 89.

Ristic, M., and Klaus, D. 2010. The meaning of $\mathrm{pH}$-value for the meat quality of broilerinfluence of breed line. Technologija mesa 51(2): 115-119

Saraswati, D. 2015. Pengaruh lama perendaman ikan tuna (Thunus albacares) dengan Air Rebusan daun Sirih (Piper Betle) terhadap pertumbuhan koloni bakteri. Jurnal kesehatan Komunitas Indonesia 11(2): $1206-1213$

Soeparno. 2005. Ilmu dan Teknologi Daging. Gajah Mada University Press. Yogyakarta.

Sudarmawan, H.P.I. 2010. Efektifitas biopreservatif berbasis bawang putih terhadap kualitas mikrobiologi bawang putih yang disimpan selama 48 jam pada suhu ruang. Skripsi. Institut Pertanian Bogor. Bogor.

Suradi, K. 2006. Perubahan sifat fisik daging ayam broiler post mortem selama penyimpanan temperatur ruang (change of physical characteristics of broiler chicken meat post mortem during room temperature storage). Jurnal Ilmu Ternak6 (1): 23 -- 27.

Taufiq, S., Yunuarti, U., dan Hazar, S. 2015. Uji aktivitas antibakteri ekstrak etanol biji buah pepaya (Carica papaya) terhadap Escherichia coli dan typhi. Prosiding Penelitian Spesia 2: 654-661

Thielke, S., Lhafi, S.K. and Ku hne, M. 2005. Effects of Aging Prior to Freezing on Poultry Meat Tenderness. Poultry Science 84:607-612

Yanti, Hidayati, H., dan Elfawati. 2008. Kualitas daging sapi degan kemasan plastik PE (Polyethylen) dan plastik PP (Polyprophylen) di Pasar Arengka Kota 
Pekanbaru. Jurnal Peternakan 5(1): 22 27

Yu, L.H., Lee, E.O., Chen, H.S., Jeong, J.Y., Choi, Y.S., Lims, D.G., and Kim, C.J. 2011. Comparison of physicochemical characteristics of hot-boned chicken breast and leg muscles during storage at $20^{\circ} \mathrm{C}$. Korean J. Food Sci. 31 (5): 676 683 